\title{
CONVERSION OF TURBOCHARGED DIESEL ENGINE TO OPERATE SOLELY WITH HYDROUS ETHANOL
}

\author{
B. L. C. Queiroga $a^{a}$, \\ E. F. Jaguaribe ${ }^{b}$, \\ M. S. J. Gonçalves', \\ B. L. N. Oliveira ${ }^{d}$, \\ and A. S. Rumão \\ ${ }^{\text {a } U n i v e r s i d a d e ~ F e d e r a l ~ d o ~ P a r a i ́ b a ~}$ \\ Departamento de Engenharia de Energias \\ Renováveis \\ Jardim Cidade Universitária \\ CP. 58059-900, João Pessoa, Paraíba, Brasil \\ bruno_queiroga@ufpi.edu.b \\ b,c,d,e Universidade Federal do Paraíba \\ Departamento de Engenharia Mecânica \\ Jardim Cidade Universitária \\ CP. 58059-900, J. Pessoa, Paraíba, Brasil. \\ Received: December 9, 2012 \\ Revised: January 04, 2013 \\ Accepted: January 29, 2013
}

\section{ABSTRACT}

This paper discusses the conversion of a turbocharged diesel engine to operate with hydrous ethanol, using procedures developed in Innovation Lab of UFPB, IL. An diesel engine, brand Perkins, model 1104C-44TAG2, was converted to operate with hydrous ethanol at the time that it amended its compression ratio of 18:1 to 9.3:1, suitable for an Otto Cycle engine to non-occurrence of detonation fuel. Comparing experimental data generated for the converted engine tests (which ranged the ignition advance, stoichiometric air/fuel ratio and rotation at $1800 \mathrm{rpm}$ ) with those obtained in tests with the original engine, and converted, $45 \mathrm{kWe}$, a cost reduction of 34 $\%$ with Ignition Advance of $20^{\circ}$. It was taken into account in this analysis, and data on fuel consumption, the cost of diesel, R\$1.90/liter, and hydrous ethanol, R\$ 0.70/liter. Regarding the gaseous emissions, depending on the load, it was found that the $\mathrm{NO}_{\mathrm{X}}$ ranged from 50 to $1050 \mathrm{ppm}, \mathrm{CO}, 1$ to $3 \%$, $\mathrm{CO}_{2}, 12$ to $15 \%$ and $\mathrm{HC} 150$ to $450 \mathrm{ppm}$.

Keywords: Diesel, Hydrous Ethanol, Turbocharger, Conversion Diesel Cycle to Otto Cycle, Gaseous Emissions.

\section{INTRODUCTION}

Brazilian sugar-alcohol industries are notable by intensive use of diesel engines that serve generators, irrigation pumps, fleets of trucks and tractors. A survey in São Paulo, Brazil, showed that $55 \%$ of this state's rural irrigation is performed with diesel engines (Frizzone and Marques, 2006). The use of diesel is expensive. For example, in 2007, it was found that a distillery midsize northeastern Brazil has spent around R\$ 1,700,000.00 to irrigate 400 ha/day. This represents about $23 \%$ of the total diesel use in the industry, while their costs with diesel in tractors are around 28\% (<http://www.polobio.esalq.usp.br>, 01 Apr. 2008). Due to the ease of partially replace diesel in trucks, some distilleries in southern Brazil have employed the ethanol they produce, ensuring thus reducing of the fuel costs and emissions.

Given that: the most modern diesel engines with electronic fuel injection do not allow the use of mixtures diesel-ethanol; new diesel engines have been equipped with turbo compressors, allowing an increase in its thermal efficiency (Heywood, 1988); the Innovation Lab UFPB (IL) has been perfecting the process of conversion of Diesel Cycle to Otto Cycle, for the exclusive use of natural gas (GN), liquefied petroleum gas (LPG), and hydrous ethanol (Jaguaribe et al., 2007, Rumão, 2008, Oliveira, 2009,
Ferraz, 2010 and Queiroga, 2009); it is observed that there are technical and economic feasibility of converting the new turbo diesel engines to operate on ethanol.

This paper discusses the process of conversion, conducted by IL, in a Perkins diesel engine, model 1104C-44TAG2, stationary, turbocharged, four cylinders, with $102 \mathrm{~kW}$ of continuous electrical power, to hydrous ethanol using a system programmable injection and ignition. Converted engine performance is compared with that do diesel engine, with respect at electrical power generated, at fuel consumption, at costs power generated and emissions gaseous.

\section{METHODOLOGY}

Initial tests with the diesel engine were performed for comparison with engine after conversion. In these tests, it was used an electric dynamometer, an electronic scale and a computer. Electrical powers, from $10 \mathrm{kWe}$ up to maximum power (verified by the imminence of the brake), were imposed on the motor. The rotation was maintained at $1800 \mathrm{rpm}$, with the aid of an electronic regulator of velocity. In each power was observed fuel consumption.

To perform the conversion of the diesel engine, 
all the components of the engine feed diesel system were replaced. Pipes, pump and nozzles of diesel were replaced for ignition coils and spark plugs (characteristic of spark ignition engines). Besides these components, were added to the engine: a electronic control unit (ECU) for control of injection and ignition of the fuel, fuel injectors, fuel rail, throttle body with TPS, phonic wheel, rotation sensor, electric fuel pump, fuel pressure regulator, fuel filter and a tank where it is stored hydrous ethanol. The compression ratio the original engine was changed from 18:1 to 9.3:1, from the modification of the cylinder head and adding spacers. The selection of components and how they were installed, as well as modifications of the cylinder head, were suitable for turbocharged engines. A schematic of the motor after conversion is shown in Fig. 1.

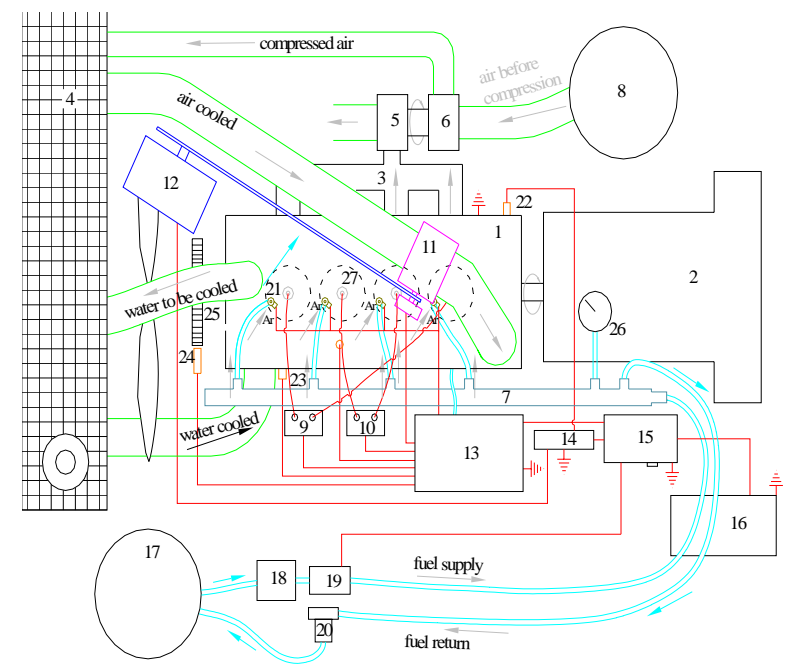

\begin{tabular}{|l|l|}
\hline \multicolumn{2}{|l|}{ Legend: } \\
\hline 1-cylinder head/intake & 14-central electronic \\
manifold; & governor; \\
2-generator of electricity; & 15-central motor starting; \\
3-exhaust manifold; & 16-battery; \\
4-radiator/after cooler; & 17-fuel tank; \\
5-turbine; & 18-fuel filter; \\
6-compressor; & 19-fuel pump; \\
7-fuel flute; & 20-fuel pressure regulator; \\
8-filter air intake; & 21-fuel injectors; \\
9-1st and 4th cylinders & 22-speed sensor electronic \\
ignition coil; & governor; \\
10-2nd and 3rd cylinders & 23-water temperature \\
ignition coil; & sensor; \\
11-throttle body; & 24-speed sensor system \\
12-actuator electronic & injection / ignition; \\
governor; & 25-phonic wheel; \\
13-UCE; & 26-gauge fuel pressure; \\
& 27-spark plugs. \\
\hline
\end{tabular}

Figure 1. Scheme engine converted after appropriate modifications to hydrous ethanol.

The tests are conducted by adjusting the engine converted for operation with stoichiometric mixtures, rotation at $1800 \mathrm{rpm}$, fuel pressure of 6 bar, varying the Ignition Advance (IA) of $12.5^{\circ}$ to $20^{\circ}$. For the evaluation of engine performance converted, beyond of the equipment used in the tests of the original engine, made up using a gas analyzer to maintain stoichiometric mixture.

\section{RESULTS AND DISCUSSION}

Figure 2 shows the data of fuel consumption as a function of electric power generated as a result of the tests with the engine originally diesel.

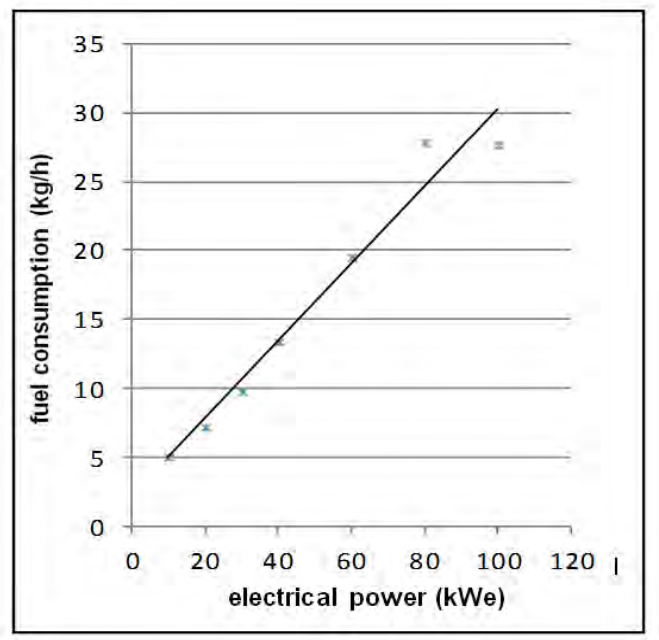

Figure 2. Fuel consumption, depending on the electric power, related to diesel.

From Fig. 2 it is observed that the engine, originally diesel, presented a fuel consumption varied from 5.07 to $27.88 \mathrm{~kg} / \mathrm{h}$, depending on the electrical power generated. The maximum power achieved was $100 \mathrm{kWe}$.

Figure 3 shows the data of fuel consumption as a function of electrical power generated as a result of the tests with the converted engine.

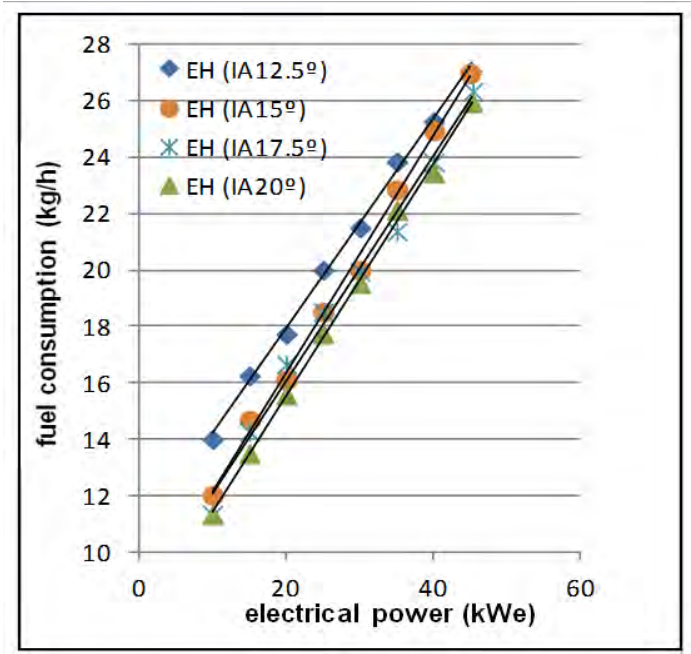

Figure 3. Fuel consumption, depending on the electrical power and IA, related to hydrous ethanol. 
From Fig. 3 it can be seen that the fuel consumption tends to increase with increasing electrical power, and with the growth of the IA, fuel consumption declines. The maximum power reached, in all configurations, was at around of $45 \mathrm{kWe}$. At maximum power, the converted engine consumed 27 $\mathrm{kg} / \mathrm{h}$ of fuel with IA $12.5^{\circ}$. Already with IA $20^{\circ}$ it showed a consumption of $25.9 \mathrm{~kg} / \mathrm{h}$.

In turn, Fig. 5 presents cost of electrical power generated, as a function of electrical power generated, considering the curves of fuel consumption (Figures 2 and 3), density of hydrous ethanol $\left(810.5 \mathrm{~kg} / \mathrm{m}^{3}\right)$ and of the diesel $\left(842.4 \mathrm{~kg} / \mathrm{m}^{3}\right)$ and the diesel and hydrous ethanol's cost of the liter to plants sugar cane, $\mathrm{R} \$ 1.90$ and $\mathrm{R} \$ 0.70$, respectively.

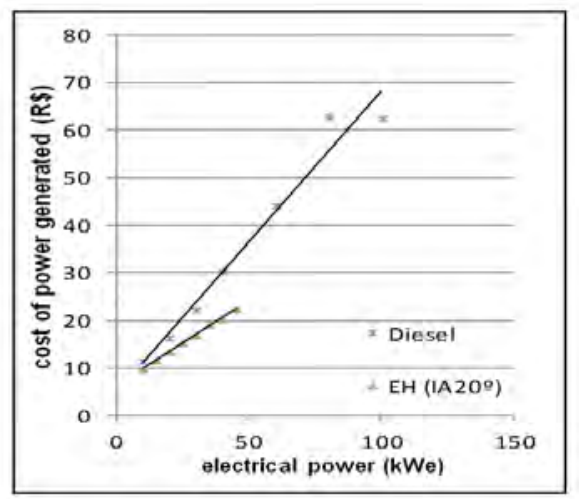

Figure 4. Graph of cost of electrical power generated by the use of hydrous ethanol and diesel, according to the electrical power generated.

According to Fig. 4, it can be seen that for all powers analyzed, the cost of power generated arising from the use of diesel remained above of generated by the use of ethanol. In particular, it was observed that the generation cost of $45 \mathrm{kWe}$ has been $\mathrm{R} \$$ 33.00, with use of diesel e R\$22.00, using ethanol.

Figures 5, 6, 7 and 8 shows the emissions of $\mathrm{CO}, \mathrm{CO}_{2}, \mathrm{HC}$ and $\mathrm{NO}_{\mathrm{X}}$ observed during the experiments with the converted engine.

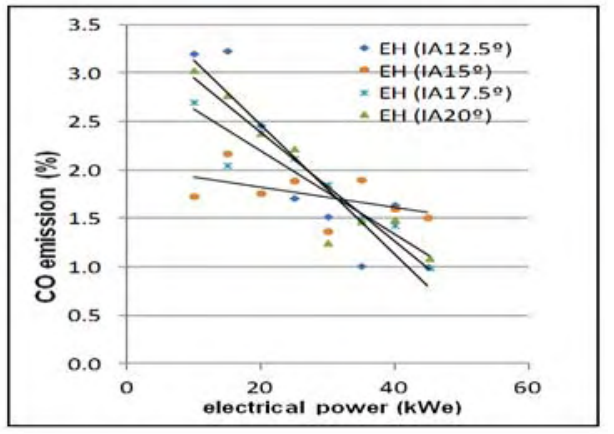

Figure 5. Graph of CO emission as a function of electrical power generated by varying the Advancement of Ignition.

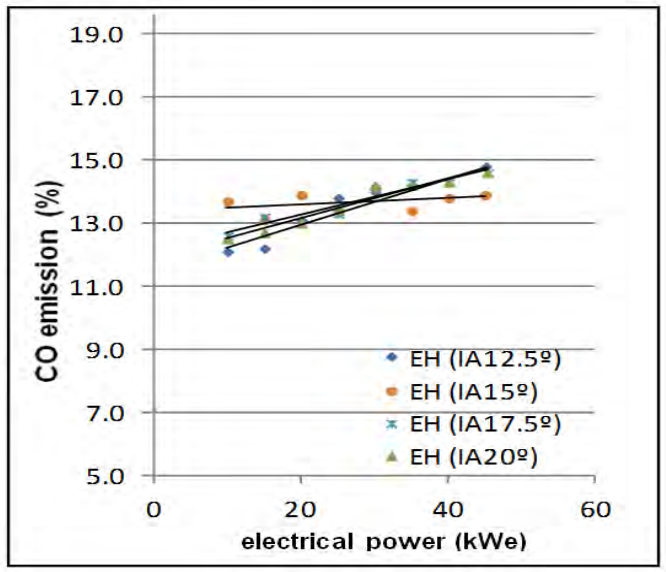

Figure 6. Graph of $\mathrm{CO}_{2}$ emission as a function of electrical power generated by varying the IA.

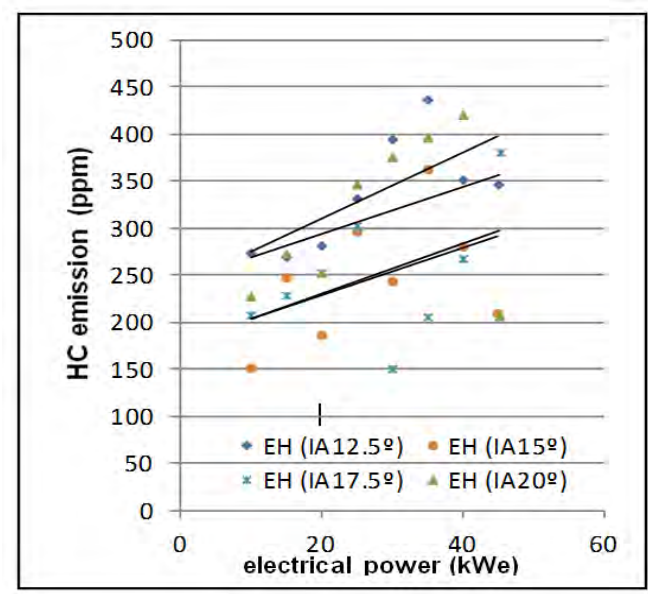

Figure 7. Graph of $\mathrm{NO}_{\mathrm{X}}$ emission as a function of electric power generated by varying the IA.

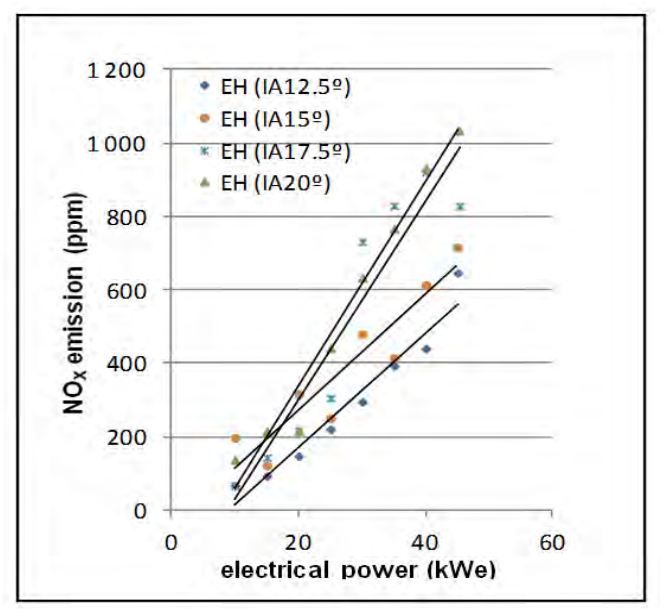

Figure 8. Graph of HC emission as a function of electric power generated by varying the IA.

The CO emission shows itself higher for greater powers, varying little with Ignition Advance. In the case of $\mathrm{CO}_{2}$ emission, was perceived an increase with the load variation and with the ignition advance. 
There was an increase in the levels of $\mathrm{HC}$ with the growth of electric power generated and in relation to $\mathrm{NO}_{\mathrm{X}}$ emissions there was a considerable changing with the increase of the power.

Depending on the load and the Ignition Advanced, $\mathrm{NO}_{\mathrm{X}}$ emissions were situated in the range of 50-1050 ppm, CO, between 1 and $3 \%, \mathrm{CO}_{2}, 12$ to $15 \%$, and the HC between 150 and 450 ppm.

\section{CONCLUSIONS}

The diesel-ethanol conversion process was based on the technique developed in the IL, where few changes are made in the original motor. In the engine evaluation were employed an electric dynamometer, a gas analyzer and an electronic scale. The supply system and ignition of the air-fuel mixture responded the needs of experimental tests.

The diesel engine, in the initials tests, reached $100 \mathrm{kWe}$, observing consumptions between 5 to 28 $\mathrm{kg} / \mathrm{h}$, depending on the load applied.

In the tests with the converted engine, at 1800 rpm, CR of 9.3:1, stoichiometric mixture, was observed lower fuel consumption in IA $20^{\circ}$. In this case, the maximum power generated was $45 \mathrm{kWe}$ with fuel consumption of $25.9 \mathrm{~kg} / \mathrm{h}$.

The CO emission shows itself higher for greater powers, varying little with Ignition Advance. In the case of $\mathrm{CO}_{2}$ emission, was perceived an increase with the load variation and with the ignition advance. There was an increase in the levels of HC with the growth of electric power generated and in relation to $\mathrm{NO}_{\mathrm{X}}$ emissions there was a considerable changing with the increase of the power. Regarding the gaseous emissions, depending on the load, it was found that the $\mathrm{NO}_{\mathrm{x}}$ ranged from 50 to $1050 \mathrm{ppm}, \mathrm{CO}$, 1 to $3 \%, \mathrm{CO} 2,12$ to $15 \%$ and $\mathrm{HC} 150$ to $450 \mathrm{ppm}$.

Analyzing the cost of power generated by the original and converted engine, it was found savings of up to $34 \%$ with ethanol use, power generating around $45 \%$ of the power of the diesel engine.

\section{REFERENCES}

Ferraz, F. B., 2010, Conversão para Gás LP de um Motor Diesel com Bicos Injetores Internos à Tampa de Tuchos, Master Thesis, Universidade Federal da Paraíba, João Pessoa, PB. (in Portuguese)

Heywood, J., 1988, Internal combustion engine fundamentals, McGraw-Hill.

Jaguaribe, E. F., Rumão A. S., Oliveira, B. L. N., Queiroga, B. L. C., Ferraz, F. B., and Filho, R. M, 2007, Desempenho de um Grupo Gerador Operando com Motor Diesel Convertido para Funcionar apenas com Gás Natural, in: $8^{\circ}$ Congresso Iberoamericano de Engenharia Mecânica, Cuscu. (in Portuguese)

Marques, P. A., Marques, T. A., and Frizzone, J. A., 2006, Viabilidade Econômica sob Condições de Risco para a Irrigação da Cana-de-Açúcar na Região de Piracicaba-SP, Irriga, Botucatu, Vol. 11, No. 1, pp. 55-65. (in Portuguese)

Oliveira, B. L. N., 2009, Conversão de um Motor a Diesel para Operar apenas com Gás Liquefeito de Petróleo, Master Thesis, Universidade Federal da Paraíba, João Pessoa, PB. (in Portuguese)

Queiroga, B. L. C., 2009, Conversão de um Motor Diesel para Álcool Hidratado usando Sistema de Injeção Eletrônica Multiponto de Combustível e Ignição Estática, Master Thesis, Universidade Federal da Paraíba, João Pessoa, PB. (in Portuguese)

Rumão, A. S., 2008, Desempenho de um Motor Diesel Estacionário Convertido para Gás Natural em Função de sua Taxa de Compressão. Master Thesis, Universidade Federal da Paraíba, João Pessoa, PB. (in Portuguese) 